\title{
Transurethral Needle Ablation of the Prostate
}

National Cancer Institute

\section{Source}

National Cancer Institute. Transurethral Needle Ablation of the Prostate. NCI Thesaurus.

Code C89821.

A procedure for treatment of benign prostatic hypertrophy that uses low energy radio frequency energy delivered through the urethra to destroy prostate tissue. 